This is the accepted manuscript of the article, which has been

published in Scandinavian Journal of Caring Sciences. 2019.

https://doi.org/10.1111/scs.12702

\title{
The consequences of having an excessively crying infant in the family: an integrative
} review by Botha, Elina; Joronen, Katja; Kaunonen, Marja

\section{Abstract}

Background: The consequences of having an excessively crying infant in the family is acknowledged in research, yet to our knowledge, no literature review has been made regarding the overall consequences to the family and infant. This integrative review fills the gap with the aim to review and synthesize current research.

Aims: To identify, describe and synthesize previous studies on the consequences of having an excessively crying infant in the family.

Design: An integrative review of literature published between January 2008 and April 2018. The search was conducted in the following databases: MEDLINE, CINAHL, PsycINFO, Medic and Journals@Ovid. Empirical literature reporting the consequences of having an excessively crying infant in the family was eligible for inclusion. Quality appraisal was performed using CASP tools and JBI checklists. The extracted data were analyzed using thematic analysis.

Findings: Thirty-one articles were included in the review. Ten themes were identified: The consequences of having an excessively crying infant in the family creates desperation, it ruins everyday life, impairs breastfeeding, isolates and casts parents into loneliness, strains and breaks family relationships with feelings of failure as a parent. The excessively crying infant in the family brings a struggle that can lead to physical and mental exhaustion. The infant may have problems later in childhood. Parents are actively trying to solve the problem and to adjust. Time allows survival with traces of negative symptoms, feelings and memories.

Conclusions: The consequences of having an excessively crying infant in the family are harmful for relationships and health. Caring for the crying infant can lead to exhaustion which might escalate into abuse. These findings help professionals understand this complex phenomenon and encourage actions for concrete support. Further research is required to explore evidence-based interventions that can help excessively crying infants and their families.

Keywords: excessive infant crying, infant colic, infant, family, integrative literature review

Introduction

The prevalent estimates of excessively crying infants are inconclusive since they vary between $3-40 \%$ and $14-30 \%(1,2)$. These variations are partly explained by inconclusive diagnosing methods and the difficulty in defining excessive crying-using experience or existing criterion. In addition, there are unreported amounts of newborns that are inconsolable at some point of their early life, with more or less serious consequences. Unexplained crying is the most common reason for pediatric consultations and hospital 
emergency department visits in the first weeks of life $(2,3)$, thus the impact of excessive infant crying on health care services is indubitable.

Crying is the only language that an infant can use to indicate a need, therefore crying is essentially a good, life protecting ability. However, if the crying persists despite the endless efforts of the parents, it becomes a problem. An inconsolable infant signal the carers' insufficiency, incompetence and unpreparedness to meet the needs of their child, which has a significant impact on the parent-infant relationship (4). Hearing the infant's cry causes distress, anxiety and hopelessness in any parent $(5,6)$. Life with the baby is nothing as the parents expected (7).

An attack of crying or extended and repeated periods of crying or fussing in an otherwise healthy infant is typically defined as "colic". A widely used criteria for colic is Wessel's (8) "rule of threes" which indicates that the infant cries for at least three hours a day, for at least three days a week, for at least three weeks in the first three to four months of life. Colic starts typically when the infant is two weeks old and continues until twelve to sixteen weeks of age. Overall, parents' experience of the crying that is inconsolable is sufficient to create disturbance in everyday life and expectations of having a baby (9) and therefore should be taken seriously.

Explaining colic is puzzling. It has been hypothesized that there may be multiple reasons for excessive infant crying. Maternal stress during pregnancy (10), pre, peri and postnatal neurophysiological, psychosocial (11) or neurological factors might be the reason for colicky crying (12). Ear infections are also considered an underlying reason for crying (13). In addition, sleeping, feeding, thermoregulation, immunological, endocrinological, gastrointestinal factors and intestinal bacteria $(14,15)$ are trying to explain excessive crying in infants. A theory has been proposed that colic is related to a complex interaction between over- and under-stimulation, state control and inborn temperament $(16,17)$.

Parents need much help and support to cope throughout the infant's colicky phase; every crying incident that the parent cannot calm is burdening $(7,11)$. There are different interventions available to calm a persistently crying infant. Evidence (18) suggests that behavioral interventions may present a solution for infant colic, but further outcome research is needed $(19,20)$.

Most adults have first or second-hand experiences of an inconsolably crying infant. This experience causes traumatic memories with discussions on different social media forums. People and professionals debate on etiology, correct diagnosis, causes and treatments. In addition, colic has provoked much research from different angles and yet left results and conclusions thin; this health problem remains still unresolved. There are studies and reviews from recent years that explain the impact that an excessively crying infant has on the parent-infant relationship (4), but a review of the broader consequences for the whole family and the infant him or herself is absent. Although it is known that excessive crying of an infant causes stress in parents and disturbs the health and dynamics in the family in several ways (4), the subject has recently been researched further. Therefore, a larger picture of the consequences of infant crying in current scientific literature needs to be outlined and updated. 
This integrative review synthesizes empirical research findings to improve the understanding of the many consequences a crying infant has on the family and on him or herself. Additionally, it highlights the need to prevent problems and to raise awareness of the families that need an intervention. It is imperative for health care professionals to understand what the complex life with a colicky infant entail and provide concrete help. Furthermore, the costs of health care can be reduced by giving parents skills to manage with their crying infant and thus avoid unnecessary and stressful visits to the emergency department $(2,3,21)$. The understanding of the risks of excessive crying might save infants' lives (22).

The review

Aim, design and search methods

The aim of this article was to identify, describe and synthesize previous studies on the consequences of having an excessively crying infant in the family. A systematic literature search was conducted according to the PRISMA statement (23). The identified literature was evaluated and appraised by two reviewers and its results were synthesized to develop common themes. An integrative literature review of 31 research articles and their findings was performed. An integrative review method (24) allowed the use of original studies with different methods, thus making possible in-depth understanding of this complex phenomenon. The review process consisted of five stages: identifying the research problem, literature search, data evaluation, data analysis and presenting the synthesis of the results.

The search was conducted in five databases during April 2018. Medline, CINAHL, Psyclnfo, Medic and Journals@Ovid were consulted to include refereed journal articles. Search terms are in Table 1.

Table 1. Study search terms

The search was limited to time between 1/2008-4/2018 to consider most recent research, and articles published in English only. Studies were excluded if they were not relevant to the review or the crying could not be separated from a cluster of regulatory problems, such as infants' eating or sleeping difficulties.

The studies, where infant crying was presented to the research objects by a recorded cry sound only, were excluded. A recording of crying does not present an authentic picture of an excessively crying infant and therefore will not measure consequences reliably.

\section{Search outcome}

Robust review methodology was used to identify studies describing the consequences of having an excessively crying infant in the family. The Preferred Reporting Items for Systematic Reviews and Meta-analyses (PRISMA) framework was used to search, identify and screen studies (23). The search and selection process of this review are outlined in Figure 1. 
After removal of duplicates, the titles and abstracts of all identified papers were initially screened against the inclusion and exclusion criteria by two independent reviewers, who discussed the results of the initial screening process to achieve consensus. In total, 28 studies met the criteria for inclusion. Three additional studies were found in the reference lists of the included studies. Finally, the integrative review included 31 studies. The included studies comprise both quantitative and qualitative empirical studies.

Figure 1 Flow chart of study selection

Quality appraisal

The quality of each research article was evaluated using CASP tools (25-27). The studies that used cross-sectional design were evaluated by JBI checklists (28), since a CASP checklist is not available for cross-sectional studies. All chosen articles were of good quality, but there were some limitations in reporting bias in measurement or in clarity of confounders. It was not seen to affect the results compromisingly.

Some studies reported only parts of a larger research, leaving other parts unexplained. None of the studies were excluded because of the above minor limitations or of inadequate scientific quality. A strength of this review and its nature is that $11 / 31$ included studies that were of large cohort longitudinal design. Longitudinal studies add to the value of this review, as long-term consequences of having an excessively crying infant in the family are addressed.

Data extraction and synthesis

Data were extracted from primary sources and analyzed using thematic analysis as described by Braun and Clarke (29). Thematic analysis is a tool for rich, detailed and complex description of collected data. The steps of the thematic analysis were familiarizing with the data, generating codes, searching for themes and naming the themes descriptively. In each step, the data corpus was re-examined to make sure no meaning was lost.

Table 3. Characteristics of included studies

Findings

Thirty-one articles were included in the final review (see Table 3). The overall quality of the included studies was good. Ten themes were identified from the included papers: The consequences of having an excessively crying infant in the family creates desperation. It ruins everyday life, impairs breastfeeding, isolates and casts into loneliness, strains and breaks family relationships and brings feelings of failure as a parent. The excessively crying infant in the family brings a struggle that can lead to physical and mental exhaustion. It places the infant at risk for danger and problems later in childhood and adolescence. Parents are actively trying to solve the problem and adjust. Time allows emerging survival with traces of negative symptoms, feelings and memories. 


\section{Summary of themes}

The excessively crying infant creates desperation in the family

The excessively crying infant causes feelings of distress, helplessness, hopelessness, anxiety and worry in his or her caretakers $(5,7,30-33)$. Feelings of shame and guilt burdens the parents $(7,34)$. The fathers of the crying infants are feeling both frustrated and angry $(31$, 35). Both parents are feeling unprepared for the situation and must process their failed expectations $(30,31,36)$. The parents' feelings might also be ambivalent $(30,35-37)$.

Excessive crying ruins everyday life

Having an excessively crying infant in the family lowers the general quality of life (38) and creates sleeping problems for the parents $(31,35,39)$. The stressful life at home can disrupt both work and sex-life (31). Dealing with inconsolable crying can result in an unhealthy escape where a parent returns to a former addiction, like smoking $(34,40,41)$.

\section{Excessive crying impairs breastfeeding}

Trying to breastfeed the infant that cries with no apparent reason is difficult. Consequently, it causes a decrease in exclusive breastfeeding and breastfeeding duration (42-44).

Inconsolable crying isolates and casts the parents into loneliness

The excessively crying infant can bring the family into social exclusion, isolation and loneliness $(7,31,36,37)$. They might seek and fail to get support from people and professionals around them $(30,35,37)$. The parents are disappointed and disillusioned with health professionals, expecting them to change in how they work $(30,37)$.

The excessively crying infant strains and breaks family relationships

The excessively crying infant strains and changes family relationships by causing marital stress, arguments and feelings of resentment towards the partner $(30,31,37,39)$. The strain of having an excessively crying infant may even advance divorce (45).

Caring for a colicky infant brings feelings of failure as a parent

The parents of an inconsolably crying infant experience feelings of incompetence, inability and inadequacy $(5,33,34,36,37,41)$. The stressful situation in the family forces the parent to renegotiate his or her identity $(30,36)$; assuming the role of a mother of father is not what they thought it would be like. The parent can become exceedingly self-critical (41) and may experience feelings of failure $(30,33)$. Moreover, the infant that cries inconsolably appears to impair parental self-efficacy $(33,46)$.

A struggle that can lead to physical and mental exhaustion 
Caring for an excessively crying infant brings exhaustion to the limits $(7,31,34,37)$. Life can turn into a burdensome struggle that affects everything else $(7,33,37,38)$. It can ultimately lead to maternal or paternal depressive symptoms $(9,35,38,39,47,48)$.

Excessive crying might place the infant at risk for danger and problems later in childhood and adolescence

Longitudinal studies indicate that excessive crying in infancy might precede antisocial behavior and conduct problems later in childhood and adolescence $(49,50)$. Excessive crying might also precede risks for hyperactivity or inattention problems later in childhood $(50,51)$. In addition, excessive crying might precede problem behavior later in childhood $(50,52)$.

Infant colic might propose a risk for mental health and emotional problems, such as anxiety, later in childhood $(50,53)$. On the other hand, the fact that the child was colicky in infancy does not predict developmental coordination disorders in childhood (54). The most dangerous consequence for the infant is that excessive crying places him or her at risk for abuse and even mortal danger. According to Talvik et al. (22), almost all parents in their study group had contacted their physicians or other specialists because of excessive crying prior to admission to a hospital with Shaken Baby Syndrome (SBS) or death.

Parents are actively trying to solve the problem and adjust

Parents are trying everything to understand and help the excessively crying infant $(7,34,37$, $55,56)$. Parents are moving forward in daily life by trial and error $(7,36,37)$. Parents are suffering together and sharing the burden (7) and taking actions to create hope in the situation (31).

Time allows emerging survival with traces of negative symptoms, feelings and memories

Parents describe emerging feelings of survival later, over time (31). Parents may start to regain confidence in parenthood as knowledge and experience builds up, and the crying is left behind. Despite this, families are left with a fading residual of negative symptoms, feelings and memories (37). Families do find relief, hope and healing with time $(7,37)$.

\section{Discussion}

This review unveils the consequences of having an excessively crying infant in the family. Prior reviews have shed light on the matter $(4,57)$ but this review, besides updating the most current research, also discovers the consequences on the infant, him or herself. The consequences of having an excessively crying infant in the family are devastating. It creates desperation in everyday life as sleeping and feeding become struggles. Crying isolates the family to the home. Excessive infant crying strains and breaks relationships between mother and father and between parent and infant (4).

Hours, days and weeks of inconsolable infant crying creates a struggle that can lead to exhaustion and ultimately - to parents' depressive symptoms. The consequences of prolonged stress and fatigue on health and wellbeing are evident $(58,59)$. Responsibility for 
a new life, mixed with exhaustion, is a challenging combination. The infant is fully dependent on the parent. In addition to caring for the infant's every basic need, close interaction is equally and vitally important. Early interaction includes eye contact, cheerful chats, gentle holding, skin-to-skin contact and cherishing new life (60), which are all endangered if the parent is exhausted or feeling depressed (61). Moreover, depression may increase the use of health care services (62).

The birth rate is decreasing in many countries (63) as people critically consider whether becoming a parent is worth the struggle. Stories and pictures of inefficacy and feelings of failure overshadow the thought of starting a family and having children or not. This gives even more reason to take the consequences of having a colicky infant in the family seriously and actively find ways to bring back the joy to parenthood.

Excessive crying places the infant at risk for danger of abuse and problems later in childhood and adolescence. Recent longitudinal research points out that waiting it out is not optimal advice for parents with an excessively crying infant in the family. For example, Smarius et al. (50) has proven that there might be previously unknown consequences for the infant in later childhood. Excessive crying might precede emotional and mental health problems later in the child's life.

Parents will go to great lengths to help their crying infant. True and false information, solutions and advice is available online and in social media. Faceless peer support may help, but it may also harm. Parents may get confused in the information overload and acquire unhelpful and even damaging advice from strangers. The professional is in a unique position to be of help. If the professional does not step up, parents will look elsewhere for advice.

The excessively crying infant increases the health care costs in the society - monetary and other. Untimely ER and other visits to the GP takes time and costs money. According to Calado et al. (3) and Halpern \& Coelho (2), excessive crying is one of the most common reasons that parents bring their infant to the hospital, mostly because they do not know what else to do. An untimely hospital visit might also mean that it is too late. Excessive crying is a known trigger for infant shaking that can lead to lethal head trauma $(22,64)$. Preventing parents from reaching the point of serious abuse is vital.

There are ways that health care professionals can support and help the family amid this chaotic time. Firstly, the issue needs to be brought up during the child's clinic visits, and not to measure and count how long the infant cries at the time or how many times a week, but emphasize on the parents' experience on how burdening it is (9). If the parent feels that the infant is inconsolable, then concrete, evidence-based advice and teaching of baby calming skills are in place. Secondly, listening and validating the issue, ensuring the parents' opportunity to discuss the situation, are also helpful. Thirdly, the parents need to be warned of danger. They need to be advised on what to do in case they approach their own limits to harm the infant.

Strengths and limitations 
The strengths of this review are that two reviewers made the study selection independently. Data extraction and thematic analysis was made in cooperation with all authors. The included literature was evaluated with checklists according to research design. Moreover, the fact that the included literature consists of heterogeneous methodology made the amount of included studies broad and therefore the results rich. In addition, 11 out of 31 research articles had a longitudinal cohort design, which strengthens the cause-effect perspective of this literature review. When researching infants and parents, it is more common to have mothers as the target group, but in many of the included studies fathers were either included in good balance or even the only subject of the research.

Nevertheless, this integrative review has limitations. The searches may not have found all the relevant studies. Some literature was excluded when excessive crying was not researched separately, but as a part of a variety of regulatory problems, such as eating and sleeping problems. This may result in some lost information.

\section{Conclusion}

This literature review found evidence that excessive infant crying has vast, lasting and farreaching consequences. In the light of this evidence, a serious health problem as this, should gain more attention amongst health professionals working with families. These consequences may affect the early interaction between parent and infant and therefore negatively affect the growth and development of the child. The relationship between the parents becomes strained and the health of everyone in the family at risk. Inconsolable crying of an infant in the early months of new life becomes chaotic instead of a happy, content and satisfying experience and may affect the families' plans to have more children in the future.

It is imperative that all advice and help from health professionals, who are in a unique position to help the families of crying babies, are based on evidence. Therefore, there is a further need to research and report interventions that can help excessively crying infants and their families in the future. A strategy for an early intervention to alleviate the burden of having an excessively crying infant has potential to strengthen the health of families from the earliest beginning. How the siblings of the excessively crying infant experience the situation, has not been researched and is a suggestion for future research.

References (*Articles included in the review.)

1 Lucassen PLB, Assendelft WJJ, van Eijk JTM, Gubbels JW, Douwes AC, van Geldrop WJ. Systematic review of the occurrence of infantile colic in the community. Arch Dis Child 2001; 84: 398-403.

2 Halpern R, Coelho R. Excessive crying in infants. Jornal de Pediatria 2016; 92: 40-45.

3 Calado CS, Pereira AG, Santos VN, Castro MJ, Maio JF. What brings newborns to the emergency department? a 1-year study. Pediatr Emerg Care 2009; 25: 244-48. 
4 Oldbury S, Adams K. The impact of infant crying on the parent-infant relationship. Community Practitioner 2015; 88: 29-34.

5 Bobevski I, Rowe H, Clarke DM, McKenzie DP, Fisher J. Early postnatal demoralisation among primiparous women in the community: measurement, prevalence and associated factors. BMC Pregnancy Childbirth 2015; 15: 259.*

6 Petzoldt J. Systematic review on maternal depression versus anxiety in relation to excessive infant crying: it is all about the timing. Archives of Women's Mental Health 2018; 21: $15-30$.

7 Landgren K, Hallström I. Parents' experience of living with a baby with infantile colic - a phenomenological hermeneutic study. Scand. J Caring Sci 2011; 25: 317-24.*

8 Wessel MA, Cobb JC, Jackson EB, Harris GS, Detwiler AC. Paroxysmal fussing in infancy, sometimes called colic. Pediatrics 1954; 14: 421-35.

9 Radesky JS, Zuckerman B, Silverstein M, Rivara FP, Barr M, Taylor JA, Lengua LJ, Barr RG. Inconsolable infant crying and maternal postpartum depressive symptoms. Pediatrics 2013; 131: $1857-64 .^{*}$

10 van der Wal MF, van Eijsden M, Bonsel GJ. Stress and emotional problems during pregnancy and excessive infant crying. J Dev Behav Pediatr 2007; 28: 431-37.

11 Schmid G, Schreier A, Meyer R, Wolke D. A prospective study on the persistence of infant crying, sleeping and feeding problems and preschool behaviour. Acta Paediatr 2010; 99 :

286-90.

12 Kotzampaltiris PV, Chou KJ, Wall SP, Crain EF. The cranial rhythmic impulse and excessive crying of infancy. J Altern Complement Med 2009; 15: 341-45.

13 Hestbaek L, Sannes MM, Lous J. Large cohort study finds a statistically significant association between excessive crying in early infancy and subsequent ear symptoms. Acta Paediatr 2014; 103: 206-11.

14 Pärtty A, Isolauri E. Gut microbiota and infant distress - the association between compositional development of the gut microbiota and fussing and crying in early infancy. Microbial Ecology in Health and Disease 2012; 26-27.

15 Sung V, Collett S, de Gooyer T, Hiscock H, Tang M, Wake M. Probiotics to prevent or treat excessive infant crying: systematic review and meta-analysis. JAMA Pediatrics 2013; 167: 1150-57.

16 Karp H. The "fourth trimester". A framework and strategy for understanding and resolving colic. Contemporary Pediatrics 2004; 21: 94-116.

$17 \mathrm{Karp} \mathrm{H}$. The fourth trimester and the calming reflex: novel ideas for nurturing young infants. Midwifery Today Int Midwife 2012; 201: 25. 
18 Joanna Briggs Institute. The effectiveness of interventions for infant colic. Best Practice: Evidence Based Information Sheets for Health Professionals 2008; 12: 1-4.

http://connect.jbiconnectplus.org/viewsourcefile.aspx?0=444 (last accessed 6 June 2018).

19 Symon B, Bammann M, Crichton G, Lowings C, Tucsok J. Reducing postnatal depression, anxiety and stress using an infant sleep intervention. BMJ Open 2012;

2:e001662.doi:10.1136/bmjopen-2012-001662 (last accessed 6 July 2018).

20 Lim S. A behavioral intervention for mothers of colicky infants [doctoral dissertation]. 2013, University of Texas, Austin.

21 Batu ED, Yeni S, Teksam O. The factors affecting neonatal presentations to the pediatric emergency department. J Emerg Med 2015; 48: 542-47.

22 Talvik I, Alexander RC, Talvik T. Shaken baby syndrome and a baby's cry. Acta Paediatr 2008; 97: 782-5.*

23 Moher D, Liberati A, Tetzlaff J, Altman DG. The PRISMA Group. Preferred reporting items for systematic reviews and meta-analyses: the PRISMA statement. PLoS Med 2009; 6: e1000097. doi:10.1371/journal.pmed1000097 (last accessed 1 August 2018).

24 Whittemore R, Knafl K. The integrative review: updated methodology. J Adv Nurs 2005; 52: 546-53.

25 Critical Appraisal Skills Programme (2018) CASP cohort study checklist. https://caspuk.net/casp-tools-checklists/ (last accessed 20 July 2018).

26 Critical Appraisal Skills Programme (2018) CASP randomised controlled trial checklist. https://casp-uk.net/casp-tools-checklists/ (last accessed 20 July 2018).

27 Critical Appraisal Skills Programme (2018) CASP qualitative checklist. https://caspuk.net/casp-tools-checklists/ (last accessed 23 July 2018).

28 Moola S, Munn Z, Tufanaru C, Aromataris E, Sears K, Sfetcu R, Currie M, Qureshi R, Mattis P, Lisy K, Mu P-F. Chapter 7: Systematic reviews of etiology and risk. In Joanna Briggs Institute Reviewer's Manual (Aromataris E, Munn Z ed.), The Joanna Briggs Institute 2017. https://reviewersmanual.joannabriggs.org/ (last accessed 12 June 2018).

29 Braun V, Clarke V. Using thematic analysis in psychology. Qualitative Research in Psychology 2006; 3: 77-101.

30 Cox $L$, Roos $V$. The experiences of first-time mothers with colic infants who seek help from medical professionals. Health SA Gesondheid 2008; 13: 4-13.*

31 Ellett MLC, Appleton MM, Sloan RS. Out of the abyss of colic: a view through the fathers' eyes. MCN Am J Matern Child Nurs 2009; 34: 164-171.*

32 Okamoto M, Matsuoka M. Causal model structure analysis of emotional unrest in first time mothers faced with persistent infant crying 6-7 weeks postpartum. Asian Nursing Research 2009; 3: 1-14.* 
33 Tabuchi N, Shimada K, Kameda Y, Sekizuka N, Sakai A. Mother's feelings of distress and related factors resulting from the crying of her one-month-old infants. Journal of Japan Academy of Midwifery 2008; 22: 25-36.*

34 Nash C, Morris J, Goodman B. A study describing mothers' opinions of the crying behaviour of infants under one year of age. Child Abuse Review 2008; 17: 191-200.*

35 Cook F, Giallo R, Petrovic Z, Coe A, Seymour M, Cann W, Hiscock H. Depression and anger in fathers of unsettled infants: a community cohort study. J Paediatr Child Health 2017; 53 : 131-5.*

36 Megel ME, Wilson ME, Bravo K, McMahon N, Towne A. Baby lost and found: mothers' experiences of infants who cry persistently. Journal Of Pediatric Health Care 2011; 25: 144152.*

37 Landgren K, Lundqvist A, Hallström I. Remembering the chaos - but life went on and the wound healed. A four year follow up with parents having had a baby with infantile colic. The Open Nursing Journal 2012; 6: 53-61.*

38 Abacı FB, Gökçe S, Tuygun N, Karacan CD, Öner Ö. Psychosocial status and quality of life in mothers of infants with colic. Turk J Pediatr 2013; 55: 391-5.*

39 Brand S, Furlano R, Sidler M, Schulz J, Holsboer-Trachsler E. Associations between infants' crying, sleep and cortisol secretion and mother's sleep and well-being. Neuropsychobiology 2014; 69: 39-51.*

40 Gaffney KF, Henry LL, Douglas CY, Goldberg PA. Tobacco use triggers for mother of infants: implications for pediatric nursing practice. Pediatric nursing 2008; 34: 253-8.*

41 Gaffney KF, Beckwitt AE, Friesen MA. Mothers' reflections about infant irritability and postpartum tobacco use. Birth 2008; 35: 66-72.*

42 Karaçam Z. Factors affecting exclusive breastfeeding of healthy babies aged zero to four months: a community-based study of Turkish women. Journal of Clinical Nursing 2008; 17: 341-9.*

43 Taut C, Kelly A, Zgaga L. The association between infant temperament and breastfeeding duration: a cross-sectional study. Breastfeeding Medicine 2016; 11: 111-8.*

44 Yalçin SS, Kuşkonmaz B. Relationship of lower breastfeeding score and problems in infancy. Breastfeeding Medicine 2011; 6: 205-8.*

45 Fallesen P, Breen R. Temporary life changes and the timing of divorce. Demography 2016; 53: 1377-98.*

46 Troutman B, Moran TE, Arndt S, Johnson RF, Chmielewski M. Development of parenting self-efficacy in mothers of infants with high negative emotionality. Infant Mental Health Journal 2012; 33: 45-54.* 
47 Howell EA, Mora PA, DiBonaventura MD, Leventhal H. Modifiable factors associated with changes in postpartum depressive symptoms. Archives of Women's Mental Health 2009; 12: 113-20.*

48 Vik T, Grote V, Escribano J, Socha J, Verduci E, Fritsch M, Carlier C, von Kries R, Koletzko B. Infantile colic, prolonged crying and maternal postnatal depression. Acta Paediatr 2009; 98: 1344-8.*

49 Goodnight JA, Donahue KL, Waldman ID, Hulle CA, Rathouz PJ, Lahey BB, D'Onofrio BM. Genetic and environmental contributions to associations between infant fussy temperament and antisocial behavior in childhood and adolescence. Behav Genet 2016; 46: 680-92.*

50 Smarius LCA, Strieder TGA, Loomans EM, Doreleijers TAH, Vrijkotte TGM, Gemke RJ, van Eijsden M. Excessive infant crying doubles the risk of mood and behavioral problems at age 5: evidence for mediation by maternal characteristics. Eur Child Adolesc Psychiatry 2017; 26: 293-302.*

51 Kaymaz N, Uzun ME, Cevizci S, Yildirim Ş, Ilçin M, Topaloğolu N, Binnetoğlu FK, Tekin M, Gökten ES. Attention deficit and hyperactivity disorder and infantile colic. Minerva Pediatr 2015; 67: 391-9.*

52 Santos IS, Matijasevich A, Capilheira MF, Anselmi L, Barros FC. Excessive crying at 3 months of age and behavioural problems at 4 years age: a prospective cohort study. $J$ Epidemiol Community Health 2015; 69: 654-9.*

53 Brown M, Heine RG, Jordan B. Health and well-being in school-age children following persistent crying in infancy. J Paediatr Child Health 2009; 45: 254-262.*

54 Milidou I, Lindhard MS, Søndergaard C, Olsen J, Henriksen TB. Developmental coordination disorder in children with a history of infantile colic. J Pediatr 2015; 167: 72530.*

55 Poskey G, PizurBarnekow K, Hersch G. Parents' response to infant crying: contributing factors of the reciprocal interaction. Journal of Occupational Science 2014; 21: 519-26.*

56 Worobey J, Peña J, Ramos I, Espinosa C. Infant difficulty and early weight gain: does fussing promote overfeeding? Maternal \& Child Nutrition 2014; 10: 295-303.*

57 Kurth E, Kennedy HP, Spichiger E, Hösli I, Zemp Stutz E. Crying babies, tired mothers: what do we know? A systematic review. Midwifery 2011; 27: 187-194.

58 Giallo R, Rose N, Cooklin A, McCormack D. In survival mode: mothers and fathers' experiences of fatigue in the early parenting period. Journal of Reproductive \& Infant Psychology 2013; 31: 31-45.

59 Wells ME, Vaughn BV. Poor sleep challenging the health of a nation. Neurodiagnostic Journal 2012; 52: 233-249. 
60 Tronick E. Emotions and emotional communication in infants. Am Psychol 1989; 44: 1129.

61 Sethna V, Murray L, Netsi E, Psychogiou L, Ramchandani PG. Paternal depression in the postnatal period and early father-infant interactions. Parenting: Science \& Practice 2015; 15: $1-8$.

62 Le HND, Gold L, Mensah FK, Cook F, Bayer JK, Hiscock H. Health service use and costs for infant behaviour problems and maternal stress. Journal of Paediatrics \& Child Health 2016; 52: 402-9.

63 EUROSTAT (1990) European Commission. Your key to European statistics. https://ec.europa.eu/eurostat/web/main/home (last accessed 20 August 2018).

64 Barr RG, Fairbrother N, Pauwels J, Green J, Chen M, Brant R. Maternal frustration, emotional and behavioural responses to prolonged infant crying. Infant Behavior \& Development 2014; 37: 652-664.

Table 1 Study search terms

\begin{tabular}{|c|c|}
\hline Keywords & Search terms $(*=$ truncation) \\
\hline Family & $\begin{array}{l}\text { famil*, mother*, father*, maternal*, } \\
\text { paternal*, parent*, sibling* }\end{array}$ \\
\hline Crying & colic*, fuss* ${ }^{*}$, cry*, irritab* \\
\hline Infant & $\begin{array}{l}\text { infant*, newborn*, bab*, neonate*, "three } \\
\text { month*" }\end{array}$ \\
\hline
\end{tabular}

Table 3 Characteristics of included studies

\begin{tabular}{|c|c|c|c|}
\hline $\begin{array}{l}\text { Authors, year } \\
\text { and country }\end{array}$ & Purpose & Design \& Measure & Sample \\
\hline $\begin{array}{l}\text { Abacl, Gökçe, } \\
\text { Tuygun, Karacan, } \\
\text { Öner (2013) } \\
\text { Turkey }\end{array}$ & $\begin{array}{l}\text { To measure the } \\
\text { psychosocial status and } \\
\text { quality of life in } \\
\text { mothers of babies with } \\
\text { infantile colic (IC). }\end{array}$ & $\begin{array}{l}\text { Quantitative, cross-sectional, } \\
\text { randomized control trial. BDI } \\
\text { to measure depression, STAI- } \\
1 \text { and STAI-2 for level of } \\
\text { anxiety (stait and trait) and } \\
\text { quality of life (Short Form- } \\
\text { 36). }\end{array}$ & $\begin{array}{l}78 \text { mother-infant } \\
\text { dyads (Group 1: } n= \\
39, \text { Group } 2: n=39 \text { ). } \\
\text { Mean age in group } \\
1 \text { was } 26 \text { years and } \\
25.3 \text { years in group } \\
2 .\end{array}$ \\
\hline $\begin{array}{l}\text { Bobevski, Rowe, } \\
\text { Clarke, } \\
\text { McKenzie, Fisher } \\
\text { (2015) } \\
\text { Australia }\end{array}$ & $\begin{array}{l}\text { To examine } 1 \text {. The } \\
\text { psychometric } \\
\text { properties of the } \\
\text { Demoralization Scale in } \\
\text { a community setting } \\
\text { and } 2 \text {. The prevalence } \\
\text { of demoralisation } \\
\text { symptoms among } \\
\text { primiparous women in } \\
\text { the community and } 3 \text {. }\end{array}$ & $\begin{array}{l}\text { Quantitative, cross-sectional } \\
\text { study that based on a cluster } \\
\text { randomised control trial. } \\
\text { Telephone questionnaire } \\
\text { interview using the } \\
\text { Demoralisation Scale. }\end{array}$ & $\begin{array}{l}400 \text { primiparous } \\
\text { women attending } \\
\text { community } \\
\text { maternal health } \\
\text { centers. Mean age: } \\
31.0 \text { years. }\end{array}$ \\
\hline
\end{tabular}




\begin{tabular}{|c|c|c|c|}
\hline & $\begin{array}{l}\text { Factors that are } \\
\text { uniquely associated } \\
\text { with demoralization in } \\
\text { the early postnatal } \\
\text { period. }\end{array}$ & & \\
\hline $\begin{array}{l}\text { Brand, Furlano, } \\
\text { Sidler, Schulz, } \\
\text { Holsboer- } \\
\text { Trachsler (2014) } \\
\text { Switzerland }\end{array}$ & $\begin{array}{l}\text { To examine the link } \\
\text { between cortisol } \\
\text { secretion, crying and } \\
\text { sleeping of infants } \\
\text { characterized by } \\
\text { infantile colic and } \\
\text { mothers' psychological } \\
\text { well-being and own } \\
\text { sleep. }\end{array}$ & $\begin{array}{l}\text { Quantitative, correlational } \\
\text { study. Questionnaires } \\
\text { regarding the infant's crying } \\
\text { and sleeping patterns. } \\
\text { Infant's sleep was objectively } \\
\text { assessed with actigraphs. } \\
\text { Cortisol secretion was } \\
\text { measured by saliva samples } \\
\text { in the mornings. After } 4 \\
\text { weeks, infants were assessed } \\
\text { again. Mothers completed } \\
\text { questionnaires assessing } \\
\text { their psychological well- } \\
\text { being and sleep. }\end{array}$ & $\begin{array}{l}24 \text { mothers and } \\
\text { infants (mean age } 8 \\
\text { weeks). Mean age: } \\
35.04 \text { years. }\end{array}$ \\
\hline $\begin{array}{l}\text { Brown, Heine, } \\
\text { Jordan (2009) } \\
\text { Australia }\end{array}$ & $\begin{array}{l}\text { To examine the } \\
\text { physical and mental } \\
\text { health outcomes at } \\
\text { school-age of a cohort } \\
\text { of children who } \\
\text { participated in a } \\
\text { randomised clinical trial } \\
\text { of treatments for } \\
\text { persistent crying in } \\
\text { infancy. }\end{array}$ & $\begin{array}{l}\text { Quantitative, longitudinal } \\
\text { follow-up study to a prior } \\
\text { randomised clinical trial. } \\
\text { Participants were compared } \\
\text { to community samples. } \\
\text { Participants and parents, } \\
\text { who were hospitalized for } \\
\text { persistent crying in infancy, } \\
\text { attended a physical } \\
\text { examination and clinical } \\
\text { mental health assessment of } \\
\text { the children. Parents } \\
\text { completed a number of } \\
\text { questionnaires that assess } \\
\text { child utilization of health } \\
\text { services, sleeping habits, } \\
\text { mental health problems, } \\
\text { well-being, child vulnerability } \\
\text { and recent life events etc. }\end{array}$ & $\begin{array}{l}75 \text { infant-parent } \\
\text { dyads participated. } \\
\text { Children aged 5-8 } \\
\text { years old. }\end{array}$ \\
\hline $\begin{array}{l}\text { Cook, Giallo, } \\
\text { Petrovic, Coe, } \\
\text { Seymour, Cann, } \\
\text { Hiscock (2017) } \\
\text { Australia }\end{array}$ & $\begin{array}{l}\text { To examine the } \\
\text { relationship between } \\
\text { unsettled infant } \\
\text { behaviour and fathers' } \\
\text { depressive symptoms, } \\
\text { cognitions surrounding } \\
\text { infant sleep and } \\
\text { personal sleep in a } \\
\text { community cohort. }\end{array}$ & $\begin{array}{l}\text { Quantitative, community } \\
\text { cohort study. Measures } \\
\text { included father report of } \\
\text { infant sleep and crying } \\
\text { problems, depressive } \\
\text { symptoms, cognitions about } \\
\text { infant sleep and own sleep } \\
\text { quality and quantity. }\end{array}$ & $\begin{array}{l}102 \text { fathers of } \\
\text { healthy infants at } 4 \\
\text { weeks, } 4 \text { months } \\
\text { and } 6 \text { months of } \\
\text { age. Mean age: } 35,7 \\
\text { years. }\end{array}$ \\
\hline $\begin{array}{l}\text { Cox, Roos (2008) } \\
\text { South Africa }\end{array}$ & $\begin{array}{l}\text { To describe the } \\
\text { experiences of first- } \\
\text { time mothers who seek }\end{array}$ & $\begin{array}{l}\text { Qualitative, exploratory, } \\
\text { descriptive and contextual. } \\
\text { In-depth, semi-structured, } \\
\text { phenomenological }\end{array}$ & $\begin{array}{l}6 \text { participants. } \\
\text { Purposive sampling } \\
\text { of first-time } \\
\text { mothers between }\end{array}$ \\
\hline
\end{tabular}




\begin{tabular}{|c|c|c|c|}
\hline & $\begin{array}{l}\text { medical help for their } \\
\text { colicky infants. }\end{array}$ & $\begin{array}{l}\text { interviews, which were } \\
\text { analysed by descriptive } \\
\text { analysis. }\end{array}$ & $\begin{array}{l}25-35 \text { years of age, } \\
\text { that sought help for } \\
\text { their infant's crying. } \\
\text { Infants were } \\
\text { between } 0-12 \\
\text { months of age. }\end{array}$ \\
\hline $\begin{array}{l}\text { Ellett, Appleton, } \\
\text { Sloan (2009) } \\
\text { USA }\end{array}$ & $\begin{array}{l}\text { To describe fathers' } \\
\text { experiences of living } \\
\text { with a colicky infant. }\end{array}$ & $\begin{array}{l}\text { Qualitative, interpretive } \\
\text { phenomenological research. } \\
\text { In-depth interviews. }\end{array}$ & $\begin{array}{l}10 \text { fathers between } \\
\text { the ages of } 19-45 .\end{array}$ \\
\hline $\begin{array}{l}\text { Fallesen, Breen } \\
\text { (2016) } \\
\text { Sweden }\end{array}$ & $\begin{array}{l}\text { To study how a } \\
\text { temporary life change, } \\
\text { such as having a child } \\
\text { with infantile colic, may } \\
\text { affect the timing of } \\
\text { divorce. }\end{array}$ & $\begin{array}{l}\text { Quantitative, longitudinal } \\
\text { study, developing and testing } \\
\text { a Bayesian learning model on } \\
\text { data of couples who had a } \\
\text { child in } 1995 \text {, and following } \\
\text { up their relationship status } \\
\text { until } 2006 \text {. }\end{array}$ & $\begin{array}{l}4920 \text { randomly } \\
\text { sampled couples } \\
\text { from a Danish } \\
\text { longitudinal survey } \\
\text { of Children (DALSC) } \\
\text { who lived in the } \\
\text { same address and } \\
\text { both registered as } \\
\text { parents. }\end{array}$ \\
\hline $\begin{array}{l}\text { Gaffney, } \\
\text { Beckwitt, Friesen } \\
\text { (2008) } \\
\text { USA }\end{array}$ & $\begin{array}{l}\text { To describe mothers' } \\
\text { reflections of perceived } \\
\text { infant irritability and } \\
\text { postpartum tobacco } \\
\text { use. }\end{array}$ & $\begin{array}{l}\text { Qualitative, descriptive study } \\
\text { of mother's who participated } \\
\text { in a mixed-methods study of } \\
\text { smoking relapse in women } \\
\text { postpartum. This adds } \\
\text { qualitative data to the prior } \\
\text { study (Gaffney et. al. 2008). } \\
\text { Semi-structured interviews. }\end{array}$ & $\begin{array}{l}86 \text { mothers who } \\
\text { intended to stay } \\
\text { smoke-free } \\
\text { postpartum. Ages } \\
\text { between 20-30 } \\
\text { years. }\end{array}$ \\
\hline $\begin{array}{l}\text { Gaffney, Henry, } \\
\text { Douglas, } \\
\text { Goldberg (2008) } \\
\text { USA }\end{array}$ & $\begin{array}{l}\text { To extend knowledge } \\
\text { of tobacco use } \\
\text { triggered by mothers or } \\
\text { infants. }\end{array}$ & $\begin{array}{l}\text { Quantitative, descriptive, } \\
\text { correlational and cross- } \\
\text { sectional design. } \\
\text { Comparative analyses were } \\
\text { made for } 3 \text { groups formed } \\
\text { based on their intentions to } \\
\text { be nonsmokers after delivery } \\
\text { and actual smoking behavior } \\
2 \text { weeks after birth. }\end{array}$ & $\begin{array}{l}130 \text { mothers of } \\
\text { infants from a study } \\
\text { of smoking relapse. } \\
\text { Mean age: } 23.2 \\
\text { years. }\end{array}$ \\
\hline $\begin{array}{l}\text { Goodnight, } \\
\text { Donahue, } \\
\text { Waldman, Hulle, } \\
\text { Rathouz, Lahey, } \\
\text { D'Onofrio (2016) } \\
\text { USA }\end{array}$ & $\begin{array}{l}\text { To gain understanding } \\
\text { of genetic and } \\
\text { environmental } \\
\text { contributions to } \\
\text { associations between } \\
\text { temperamental } \\
\text { fussiness and ASB } \\
\text { (Antisocial Behaviour) } \\
\text { in childhood and late } \\
\text { adolescence. }\end{array}$ & $\begin{array}{l}\text { Quantitative, longitudinal, } \\
\text { cohort study. Comparison of } \\
\text { siblings and bivariate } \\
\text { biometric modeling, to } \\
\text { reduce familial confounding } \\
\text { and examine genetic and } \\
\text { environmental influences. }\end{array}$ & $\begin{array}{l}\text { Participants came } \\
\text { from a prospective } \\
\text { cohort ( } 9237 \text { at } 4-9 \\
\text { years and } 7034 \text { at } \\
14-17 \text { years), the } \\
\text { children of a } \\
\text { national sample of } \\
\text { US women. }\end{array}$ \\
\hline $\begin{array}{l}\text { Howell, Mora, } \\
\text { DiBonaventura, } \\
\text { Leventhal (2009) } \\
\text { USA }\end{array}$ & $\begin{array}{l}\text { To identify modifiable } \\
\text { factors associated with } \\
\text { postpartum depressive } \\
\text { symptoms. }\end{array}$ & $\begin{array}{l}\text { Quantitative, longitudinal, } \\
\text { observational prospective } \\
\text { cohort telephone study. } \\
\text { Mothers answered questions } \\
\text { on demographic factors, }\end{array}$ & $\begin{array}{l}563 \text { mothers were } \\
\text { interviewed at } 2 \\
\text { weeks and } 6 \\
\text { months }\end{array}$ \\
\hline
\end{tabular}




\begin{tabular}{|c|c|c|c|}
\hline & & $\begin{array}{l}\text { physical and emotional } \\
\text { symptoms, daily function, } \\
\text { infant behavior, social } \\
\text { support and skills in } \\
\text { managing infant and } \\
\text { household. }\end{array}$ & $\begin{array}{l}\text { postpartum. Mean } \\
\text { age: } 31 \text { years. }\end{array}$ \\
\hline $\begin{array}{l}\text { Karaçam (2008) } \\
\text { Turkey }\end{array}$ & $\begin{array}{l}\text { To determine the } \\
\text { factors that affect } \\
\text { exclusive breastfeeding } \\
\text { on healthy infants aged } \\
0-4 \text { months. }\end{array}$ & $\begin{array}{l}\text { Quantitative, cross-sectional } \\
\text { design. Questionnaire } \\
\text { included independent } \\
\text { variables, background } \\
\text { questions, EPDS, the } \\
\text { Multidimensional Scale of } \\
\text { Perceived Social Support } \\
\text { (MSPSS) and baby's form of } \\
\text { nutrition. }\end{array}$ & $\begin{array}{l}514 \text { mothers, } \\
\text { selected by } \\
\text { convenience } \\
\text { sampling method } \\
\text { among mothers } \\
\text { who visited the } \\
\text { health care centre } \\
\text { for baby checkups } \\
\text { and immunizations. } \\
\text { Mean age: } 26 \text { years. }\end{array}$ \\
\hline $\begin{array}{l}\text { Kaymaz, Uzun, } \\
\text { Cevizci, Yildirim, } \\
\text { Ilçin, Topaloğolu, } \\
\text { Binnetoğlu, } \\
\text { Tekin, Gökten } \\
\text { (2015) } \\
\text { Turkey }\end{array}$ & $\begin{array}{l}\text { To investigate the } \\
\text { relationship between } \\
\text { infantile colic, attention } \\
\text { deficit and } \\
\text { hyperactivity disorder } \\
\text { due to possible } \\
\text { common etiological } \\
\text { factor as } \\
\text { maldevelopment in the } \\
\text { neurochemical process. }\end{array}$ & $\begin{array}{l}\text { Quantitative, case-control } \\
\text { study. Parents and teachers } \\
\text { answered CPRS and CTRS and } \\
\text { patients were evaluated with } \\
\text { DSM-IV. }\end{array}$ & $\begin{array}{l}114 \text { children who } \\
\text { were medically } \\
\text { diagnosed with } \\
\text { ADHD and } 149 \\
\text { healthy children as } \\
\text { the control group } \\
\text { (same hospital's } \\
\text { pediatric clinic). } \\
\text { Mean age of ADHD } \\
\text { group was } 10.14 \\
\text { years and } 9.94 \\
\text { years in the control } \\
\text { group. }\end{array}$ \\
\hline $\begin{array}{l}\text { Landgren, } \\
\text { Hallström (2011) } \\
\text { Sweden }\end{array}$ & $\begin{array}{l}\text { To bring forward the } \\
\text { meaning of what it is } \\
\text { like to be a parent of an } \\
\text { infant with colic. }\end{array}$ & $\begin{array}{l}\text { Qualitative, } \\
\text { phenomenological } \\
\text { hermeneutic study using } \\
\text { qualitative inductive } \\
\text { interview with narrative } \\
\text { analysis. }\end{array}$ & $\begin{array}{l}23 \text { parents (12 } \\
\text { mothers and } 11 \\
\text { fathers) looking for } \\
\text { help for excessive } \\
\text { crying at the child } \\
\text { health clinic. Mean } \\
\text { ages: Babies: } 9.6 \\
\text { weeks. Mothers } \\
29.8 \text { years. Fathers } \\
31.7 \text { years. }\end{array}$ \\
\hline $\begin{array}{l}\text { Landgren, } \\
\text { Lundqvist, } \\
\text { Hallström (2012) } \\
\text { Sweden }\end{array}$ & $\begin{array}{l}\text { To describe parent's } \\
\text { experience of having } \\
\text { had a baby with colic } \\
\text { four years prior and of } \\
\text { how the colic and care } \\
\text { influenced the family in } \\
\text { a long-term } \\
\text { perspective. }\end{array}$ & $\begin{array}{l}\text { Qualitative, longitudinal, } \\
\text { inductive follow-up research. } \\
\text { Interview narratives were } \\
\text { analysed with content } \\
\text { analysis. } 13 \text { individual and } 1 \\
\text { focus group interview with } 4 \\
\text { parents. }\end{array}$ & $\begin{array}{l}10 \text { mothers and } 7 \\
\text { fathers } \\
\text { (representing } 12 \\
\text { families who were } \\
\text { interviewed } 4 \text { years } \\
\text { earlier during their } \\
\text { baby's colicky } \\
\text { period). Parents } \\
\text { ages ranged } \\
\text { between 26-56 } \\
\text { years. }\end{array}$ \\
\hline
\end{tabular}




\begin{tabular}{|c|c|c|c|}
\hline $\begin{array}{l}\text { Megel, Wilson, } \\
\text { Bravo, } \\
\text { McMahon, } \\
\text { Towne (2011) } \\
\text { USA }\end{array}$ & $\begin{array}{l}\text { To describe mothers' } \\
\text { experiences of } \\
\text { parenting an irritable } \\
\text { infant. }\end{array}$ & $\begin{array}{l}\text { Qualitative, grounded } \\
\text { theory, interviews with open- } \\
\text { ended questions. }\end{array}$ & $\begin{array}{l}12 \text { mothers. Mean } \\
\text { age: } 27 \text { years. }\end{array}$ \\
\hline $\begin{array}{l}\text { Milidou, } \\
\text { Lindhard, } \\
\text { Søndergaard, } \\
\text { Olsen, Henriksen } \\
\text { (2015) } \\
\text { Denmark }\end{array}$ & $\begin{array}{l}\text { To investigate whether } \\
\text { children with a history } \\
\text { of infantile colic } \\
\text { showed impaired } \\
\text { motor development at } \\
\text { age } 7 \text { years compared } \\
\text { with unaffected peers. }\end{array}$ & $\begin{array}{l}\text { Quantitative, cohort, } \\
\text { longitudinal, follow-up study. } \\
\text { Comparing the DCDQ'07 } \\
\text { scores in children with and } \\
\text { without colic after } \\
\text { adjustment for intrauterine } \\
\text { exposure, feeding type, } \\
\text { parity, maternal age etc. }\end{array}$ & $\begin{array}{l}27940 \text { children from } \\
\text { the Danish National } \\
\text { Birth Cohort (1997- } \\
2002 \text { ), including } \\
1879 \text { with a history } \\
\text { of infant colic. }\end{array}$ \\
\hline $\begin{array}{l}\text { Nash, Morris, } \\
\text { Goodman (2008) } \\
\text { UK }\end{array}$ & $\begin{array}{l}\text { To describe mothers' } \\
\text { opinions of the crying } \\
\text { behavior of infants } \\
\text { under one year of age. }\end{array}$ & $\begin{array}{l}\text { Qualitative, descriptive study } \\
\text { using semi-structured } \\
\text { interviews. }\end{array}$ & $\begin{array}{l}24 \text { mothers and } 2 \\
\text { fathers visiting a } \\
\text { child health clinic. } \\
\text { Parents age ranged } \\
\text { between } 18-42 \\
\text { years. Infants age } \\
\text { ranged between } 3- \\
12 \text { months of age. }\end{array}$ \\
\hline $\begin{array}{l}\text { Okamoto, } \\
\text { Matsuoka (2009) } \\
\text { Japan }\end{array}$ & $\begin{array}{l}\text { To understand causal } \\
\text { factors associated with } \\
\text { emotional unrest } \\
\text { among first-time } \\
\text { mothers with a } \\
\text { persistently crying } \\
\text { infant. }\end{array}$ & $\begin{array}{l}\text { Quantitative, cross-sectional } \\
\text { survey. Causal factors for } \\
\text { emotional unrest were } \\
\text { explored using structural } \\
\text { equation modeling. }\end{array}$ & $\begin{array}{l}217 \text { first time } \\
\text { mothers with } \\
\text { infants aged } 6-7 \\
\text { weeks. Mean age: } \\
30.57 \text { and } 29.71 \\
\text { years. }\end{array}$ \\
\hline $\begin{array}{l}\text { Poskey, Pizur- } \\
\text { Barnekow, } \\
\text { Hersch (2014) } \\
\text { USA }\end{array}$ & $\begin{array}{l}\text { To explore parents' } \\
\text { thoughts, feelings, } \\
\text { behaviors and actions } \\
\text { in response to } \\
\text { inconsolable infant } \\
\text { crying. }\end{array}$ & $\begin{array}{l}\text { Qualitative, ethnographic } \\
\text { study observing parents and } \\
\text { crying infants in their homes. } \\
\text { Data by field notes ( } 7 \\
\text { observations in participants } \\
\text { homes) and brief } \\
\text { questionnaire. }\end{array}$ & $\begin{array}{l}4 \text { parents ( } 2 \text { males } \\
\text { and } 2 \text { females from } \\
\text { different } \\
\text { households) chosen } \\
\text { by convenient } \\
\text { sampling. Mean } \\
\text { age: } 34.75 \text { years. } \\
\text { Infants average age } \\
\text { were } 11 \text { weeks. }\end{array}$ \\
\hline $\begin{array}{l}\text { Radesky, } \\
\text { Zuckerman, } \\
\text { Silverstein, } \\
\text { Rivara, Barr, } \\
\text { Taylor, Lengua, } \\
\text { Barr (2013) } \\
\text { USA }\end{array}$ & $\begin{array}{l}\text { To quantify the extent } \\
\text { to which maternal } \\
\text { report of inconsolable } \\
\text { crying is associated } \\
\text { with maternal } \\
\text { depressive symptoms. }\end{array}$ & $\begin{array}{l}\text { Quantitative, nested, } \\
\text { retrospective, longitudinal, } \\
\text { cohort study based on a prior } \\
\text { RCT. } \\
\text { Data from Baby's Day Diary } \\
\text { when the infant was 5-6 } \\
\text { weeks of age. EPDS scores } \\
\text { administered at enrollment } \\
\text { and } 8 \text { weeks postpartum. }\end{array}$ & $\begin{array}{l}587 \text { mothers. Mean } \\
\text { age: } 31 \text { years. }\end{array}$ \\
\hline $\begin{array}{l}\text { Santos, } \\
\text { Matijasevich, } \\
\text { Capilheira, }\end{array}$ & $\begin{array}{l}\text { To assess the } \\
\text { prevalence of excessive } \\
\text { crying at the age of } 3 \\
\text { months and to test the }\end{array}$ & $\begin{array}{l}\text { Quantitative, population- } \\
\text { based, birth cohort perinatal } \\
\text { study. Information collected } \\
\text { during the perinatal study }\end{array}$ & $\begin{array}{l}3674 \text { mothers, who } \\
\text { replied that their } \\
\text { baby cries } \\
\text { excessively. }\end{array}$ \\
\hline
\end{tabular}




\begin{tabular}{|c|c|c|c|}
\hline $\begin{array}{l}\text { Anselmi, Barros } \\
\text { (2015) } \\
\text { Brazil }\end{array}$ & $\begin{array}{l}\text { hypothesis that } \\
\text { excessive crying at this } \\
\text { age is associated with } \\
\text { behavioral problems } \\
\text { when children are } 4 \\
\text { years old. }\end{array}$ & $\begin{array}{l}\text { and at 3-month and 48- } \\
\text { month follow-up visits. } \\
\text { Infants whose mothers } \\
\text { perceived them as crying } \\
\text { more than other babies of } \\
\text { the same age during the } 3- \\
\text { month visit were included in } \\
\text { this study. Child behavior } \\
\text { was assessed with the Child } \\
\text { Behavior Checklist (CBCL). }\end{array}$ & \\
\hline $\begin{array}{l}\text { Smarius, } \\
\text { Strieder, } \\
\text { Loomans, } \\
\text { Doreleijers, } \\
\text { Vrijkotte, } \\
\text { Gemke, van } \\
\text { Eijsden (2017) } \\
\text { The Netherlands }\end{array}$ & $\begin{array}{l}\text { To examine if excessive } \\
\text { infant crying is a } \\
\text { determinant of } \\
\text { emotional and } \\
\text { behavioral problems at } \\
\text { age } 5-6 \text { years. }\end{array}$ & $\begin{array}{l}\text { Quantitative, longitudinal } \\
\text { study that is based on a large } \\
\text { prospective, observational, } \\
\text { population-based multiethnic } \\
\text { birth cohort. Questionnaire } \\
\text { included SDQ, PAS and } \\
\text { SMFQ. }\end{array}$ & $\begin{array}{l}3369 \text { participants } \\
\text { answered all } 3 \\
\text { measurements } \\
\text { (which is } 41 \% \text { of the } \\
\text { original research } \\
\text { data from 2003) on } \\
\text { pregnancy, infancy } \\
\text { and early childhood. }\end{array}$ \\
\hline $\begin{array}{l}\text { Tabuchi, } \\
\text { Shimada, } \\
\text { Kameda, } \\
\text { Sekizuka, Sakai } \\
\text { (2008) } \\
\text { Japan }\end{array}$ & $\begin{array}{l}\text { To clarify the nature of } \\
\text { mother's distress and } \\
\text { its related factors } \\
\text { resulting from the } \\
\text { crying of her one- } \\
\text { month-old infant. }\end{array}$ & $\begin{array}{l}\text { Quantitative, descriptive, } \\
\text { self-report survey. A } \\
\text { correlation design was used } \\
\text { and data were collected } \\
\text { through a non-probability } \\
\text { sampling } \\
\text { survey using a self- } \\
\text { administered questionnaire. } \\
\text { Questionnaire included } \\
\text { questions on characteristics } \\
\text { of the infant's crying, states } \\
\text { of mother's sleep, feeding } \\
\text { and receiving support related } \\
\text { to her distress about her } \\
\text { infant and its associated } \\
\text { factors. }\end{array}$ & $\begin{array}{l}630 \text { mothers who } \\
\text { answered the } \\
\text { survey. Mean age: } \\
29 \text { years. }\end{array}$ \\
\hline $\begin{array}{l}\text { Talvik, } \\
\text { Alexander, Talvik } \\
\text { (2008) } \\
\text { Estonia }\end{array}$ & $\begin{array}{l}\text { To investigate the } \\
\text { relationship between } \\
\text { crying of an infant and } \\
\text { inflicted head injury by } \\
\text { shaking and/or impact. }\end{array}$ & $\begin{array}{l}\text { Retrospective and } \\
\text { prospective population } \\
\text { hospital record study. }\end{array}$ & $\begin{array}{l}26 \text { identified cases } \\
\text { of shaken baby } \\
\text { syndrome (SBS) in } \\
\text { children under } 1 \\
\text { year old, between } \\
\text { 1997-2003, in } \\
\text { Estonia. Mean age } \\
\text { of children: } 3.9 \\
\text { months. }\end{array}$ \\
\hline $\begin{array}{l}\text { Taut, Kelly, } \\
\text { Zgaga (2016) } \\
\text { Ireland }\end{array}$ & $\begin{array}{l}\text { To investigate } \\
\text { associations between } \\
\text { infant difficult } \\
\text { temperament and } \\
\text { breastfeeding duration. }\end{array}$ & $\begin{array}{l}\text { Quantitative, cross-sectional } \\
\text { nationally representative } \\
\text { study based on a longitudinal } \\
\text { cohort of Irish 9-month-old } \\
\text { infants. Mothers completed } \\
\text { questionnaires in infant } \\
\text { temperament (ICQ), } \\
\text { breastfeeding duration etc. }\end{array}$ & $\begin{array}{l}5955 \text { breast-fed, } \\
\text { normal birth-weight } \\
\text { singletons from the } \\
\text { Infant Cohort of the } \\
\text { Growing Up in } \\
\text { Ireland Study. }\end{array}$ \\
\hline
\end{tabular}




\begin{tabular}{|c|c|c|c|}
\hline $\begin{array}{l}\text { Troutman, } \\
\text { Moran, Arndt, } \\
\text { Johnson, } \\
\text { Chmielewski } \\
\text { (2012) } \\
\text { USA }\end{array}$ & $\begin{array}{l}\text { To examine the } \\
\text { development of } \\
\text { maternal Parenting } \\
\text { Self-Efficacy (PSE) in } \\
\text { mothers of infants with } \\
\text { high negative } \\
\text { emotionality (NE). }\end{array}$ & $\begin{array}{l}\text { Quantitative, longitudinal } \\
\text { prospective study. Observer } \\
\text { assessment of infant (NE and } \\
\text { NBAS) at 3-4 weeks } \\
\text { postpartum to find irritable } \\
\text { infants, then domain general } \\
\text { and domain specific } \\
\text { assessments of PSE at } 8 \text { and } \\
16 \text { weeks postpartum. }\end{array}$ & $\begin{array}{l}24 \text { irritable and } 29 \\
\text { nonirritable infants } \\
\text { were sampled in } \\
\text { two screening } \\
\text { sessions, from a } \\
\text { group of } 111 \\
\text { infants. Mean age: } \\
31.1 \text { years. }\end{array}$ \\
\hline $\begin{array}{l}\text { Vik, Grote, } \\
\text { Escribano, } \\
\text { Socha, Verduci, } \\
\text { Fritsch, Carlier, } \\
\text { von Kries, } \\
\text { Koletzko (2009) } \\
\text { Germany }\end{array}$ & $\begin{array}{l}\text { To study if infant crying } \\
\text { is associated with } \\
\text { maternal postnatal } \\
\text { depression. }\end{array}$ & $\begin{array}{l}\text { Quantitative, cross-sectional, } \\
\text { longitudinal, prospective } \\
\text { study based on a European } \\
\text { randomized controlled } \\
\text { multicenter study. Mothers } \\
\text { completed the Edinburgh } \\
\text { Postnatal Depression Scale } \\
\text { (EPDS), child's behavior } \\
\text { (crying) and child behavior. }\end{array}$ & $\begin{array}{l}\text { Original study with } \\
\text { a total of } 1678 \\
\text { mothers that were } \\
\text { recruited at } 11 \\
\text { study sites in five } \\
\text { European countries } \\
\text { between } 2002- \\
2004 \text {. This study } \\
\text { included } 1015 \\
\text { mothers. }\end{array}$ \\
\hline $\begin{array}{l}\text { Worobey, Peña, } \\
\text { Ramos, Espinosa } \\
\text { (2014) } \\
\text { USA }\end{array}$ & $\begin{array}{l}\text { To examine whether } \\
\text { greater infant difficulty } \\
\text { elicits more feeding, } \\
\text { which in turn leads to } \\
\text { more rapid weight gain } \\
\text { in early infancy. }\end{array}$ & $\begin{array}{l}\text { Quantitative, longitudinal } \\
\text { study. Instruments were } \\
\text { anthropometric measures, } \\
\text { mother-kept diary, infant } \\
\text { temperament assessment } \\
\text { (ICQ) and sleep duration. } \\
\text { Home visits with interviews. }\end{array}$ & $\begin{array}{l}154 \text { mother-infant } \\
\text { dyads who from } \\
\text { enrollment and for } \\
\text { whom home visits } \\
\text { were made. Infants } \\
\text { were exclusively } \\
\text { formula-fed. Mean } \\
\text { age: } 26.6 \text { years. }\end{array}$ \\
\hline $\begin{array}{l}\text { Yalçin, } \\
\text { Kuşkonmaz } \\
\text { (2011) } \\
\text { Turkey }\end{array}$ & $\begin{array}{l}\text { To determine the effect } \\
\text { of maternal and infant } \\
\text { characteristics on } \\
\text { breastfeeding scores. }\end{array}$ & $\begin{array}{l}\text { Quantitative, descriptive } \\
\text { study. Questionnaire, which } \\
\text { included background } \\
\text { information, parental } \\
\text { concern about crying and } \\
\text { colic etc. Breastfeeding was } \\
\text { evaluated and scored } \\
\text { according to the World } \\
\text { Health Organization/UNICEF } \\
\text { breast Feeding observation } \\
\text { form. }\end{array}$ & $\begin{array}{l}82 \text { mothers with } \\
\text { healthy } 2 \text {-month- } \\
\text { old infants. Mean } \\
\text { age: } 30.2 \text { years. }\end{array}$ \\
\hline
\end{tabular}

Figure 1 Flow chart of study selection 